\title{
非イオン界面活性剤非水溶液におけるイえダ ゾールの触媒作用
}

\author{
今野紀二郎・井上哲夫・花田常雄 - 中村顕二 - 北原文雄 \\ 東京理科大学工学部工業化学科 (東京都新宿区神楽坂 1-3)
Catalytic Action of Imidazole in Nonaqueous Solutions of Nonionic Surfactants

Kijiro Kon-no, Tetsuo Inoue, Tsuneo Hanada, Kenji Nakamura, and Ayao Kitahara

Department of Industrial Chemistry, Science University of Tokyo

(1-3, Kagurazaka, Shinjuku-ku, Tokyo)

\begin{abstract}
In order to examine the catalytic action of imidazole in nonaqueous solutions of nonionic surfact $=$ ants, the pseudo-first-order rate constants $\left(k_{\mathrm{obs}}\right)$ for the reaction between $p$-nitrophenyl acetate and imidazole in carbon tetrachloride was measured as a function of the concentration of imidazole at fixed molar ratios $(0.5,1.0,2.0)$ of imidazole to surfactants. By analyzing of $k_{\mathrm{obs}}$-[Imidazole] profile obtained, the second and third rate constants $\left(k_{2, \mathrm{~m}}\right.$ and $\left.k_{3, \mathrm{~m}}\right)$ for imidazole monomer and the catalytic rate constant $\left(k_{\mathrm{A}}\right)$ for imidazole aggregates were obtained. Both $k_{2, \mathrm{~m}}$ and $k_{\mathrm{A}}$ values increase with the increase in the molar ratio or the oxyethylene chain length of surfactants, but the increase is small for $k_{2, \mathrm{~m}}$. The catalytic action of imidazole in water solubilized into the imidazole/surfactant $/ \mathrm{CCl}_{4}$ systems is enhanced with decrease in polarity of the interior of aggregates.
\end{abstract}

\section{1 緒 言}

最近逆ミセル触媒は, 酵素反応及び生体膜における輸 送現象のモデルとしてばかりでなくエネルギー貯蔵庫と して有用であることが認められつつある。現在まで報告 された逆ミセル触媒反応に関する研究をその反応系から 分類してみると, 次の 3 つのカテゴリー, すなわち (1) アルキルアンモニウムカルボキシラート逆ミセルにみら れるようにそれ自身触媒作用を示す反応系 ${ }^{1) ~ 9) ，(2) ~}$ Aerosol OT やジアルキルジメチルアンモニウム=ハライ ドなどのように逆ミセルを触媒担体とする反応系 ${ }^{10) ~ 14) ~}$ (3) 逆ミセルの内部に形成する “Water pool” 中におけ る反応系 ${ }^{14) \sim 17) に わ け る こ と か ゙ て ゙ き よ う 。 ~}$

特に逆ミセルの触媒担体作用に関する研究は, 酵素反 応のモデル系として考えられ，多くの酵素分子中に存在 するイミダゾールなどを逆ミセル溶液に添加し，その系 における触媒反応 ${ }^{10) \sim 15)}$ が調べられてきたが，用いられ た界面活性剤はどの研究においてもイオン界面活性剤で あった。しかし逆ミセルの担体作用が触媒分子と界面活 性剤の極性基部との相互作用によって発現することを考 えると, イオン界面活性剂逆ミセルの外に極性基部の異 なる非イオン界面活性剤を触媒担体として用いる試みも また興味あるものと考えられる。さらにまた非イオン界
面活性剤を用いて興味あることは，イオン界面活性剂の 場合と違って無極性溶媒中で分子溶解する非イオン界面 活性剂は水などの極性物質の添加によってミセルを形成 する ${ }^{18)}$ ので, 触媒分子のモノマー及びミセル状態での反 応性を比較することが可能である。そこで本研究では, ポリオキシエチレン型非イオン界面活性剤非水溶液にイ ミダゾールを添加し，イオン界面活性剤溶液の場合 ${ }^{12)}$ 同様に界面活性剤に対するイミダゾールのモル比を一定 にした系について，p-ニトロフェニルアセタートに対 するイミダゾールの触媒作用を調べることにした。

\section{2 実験}

\section{$2 \cdot 1$ 試料}

非イオン界面活性剤として用いたドデシルポリオキシ エチレン=エーテルは，それぞれオキシエチレン基数 : 1,3,5,8 (以下それぞれ DP-1, 3,5,8 と略記する) をも つ市販品 (日本サーファクタント (株) 社製) である。 これらの界面活性剤はすべて単一のオキシエチレン鎖長 をもち，かつ高純度品であるためそのまま用いた。また 界面活性剂のオキシェチレン鎖長の効果をみるため，1ドデカノールをも比較に用いた。この試料は市販一級品 を2 回蒸留して精製した。触媒及び反応基質として用い たイミダゾール及び $p$ ーニロフェニルアセタート（以 
下 PNPA と略記する) はいずれも市販特級品でそのま ま用いた。溶媒として用いた四塩化炭素は市販特級品で 常法により精製し, Molecular Sieve 4A で充分脱水し て用いた。

\section{2 反応速度の測定}

反応はイミダゾールと界面活性剤またはドデカノール の混合溶液を $0.3 \sim 3 \mathrm{dm}^{3}$ の共せん付き石英セルに採取 し, PNPA 溶液を添加したのち，ただちにかきまぜ混合 し, 反応によって生成した $p$-ニトロフェノールの濃度の 時間変化を島津製作所 (株) 製紫外可視分光光度計 UV200 によって測定した。 $p$-ニトロフェノールの最大吸収 は $319 \mathrm{~nm}$ であった。この反応はどの系においても $\mathrm{PN}$ PA について擬一次で, その速度定数 $\left(k_{\mathrm{obsd}}\right)$ を $\mathrm{Gug}=$ genheim 法 ${ }^{19}$ 亿よって求めた。PNPA の初濃度はすべ て $6.45 \times 10^{-4} \mathrm{~mol} \cdot \mathrm{kg}^{-1}$ であり, 反応温度は $30^{\circ} \mathrm{C}$ であ った。

\subsection{NMR 及び密度測定}

NMR スペクトルは, 日立 NMR 分光光度 計 R-21 $(60 \mathrm{MHz})$ で測定した。化学シフトは外部基準としての TMS に対して ppmで示した。密度測定は Auton-Poar DM 500 デジタル密度計を用い, $30^{\circ} \mathrm{C}$ で行った。

\section{3 結果と考察}

\section{1 イミダゾール/界面活性剤/四塩化炭素系におけ る反応機構}

四塩化炭素溶媒及びイオン界面活性剤溶液の無水系及 び含水系に扔ける PNPA とイミダゾールとの反応は， NMR 測定から無水系ではイミダゾールによるアミン分 解であり，含水系では加水分解であることが知られてい $3^{12)}$ 。そこで既報 ${ }^{12)}$ の場合と同様に NMR 測定によりイ ミダゾール/界面活性剤/ $\mathrm{CCl}_{4}$ 系における PNPA の分解

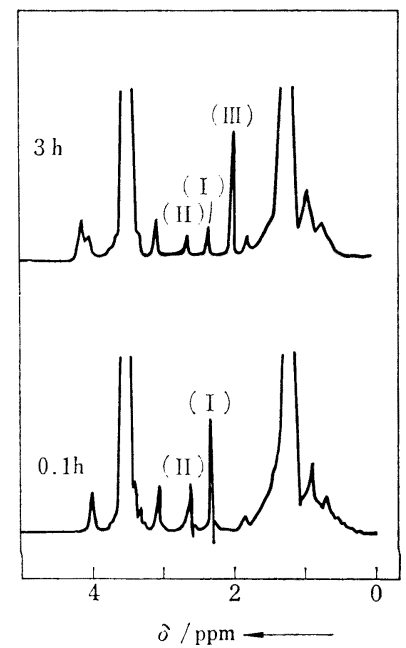

Fig. -1 NMR spectrum in anhydrous PNPA/ imidazole/DP-8/CCl ${ }_{4}$ systems.
反応の機構を調べた。Fig.-1 にはイミダゾール/DP-8/ $\mathrm{CCl}_{4}$ 無水系で反応開始後, 0.1 と $3 \mathrm{~h}$ 経過した時の NMR スペクトルを一例として示した。このスペクトル において反応中に変化する主なシグナルは，Fig.-1 中 の (I )，(II)，(III) である。これらのシグナルは DP$8 / \mathrm{CCl}_{4}$ 系に PNPA, アセチルイミダゾール及びドデシ ルアセタートを添加して同定した結果, $2.30 \mathrm{ppm}$ のシ グナル (I ) は PNPA の- $\mathrm{COCH}_{3}, 2.58 \mathrm{ppm}$ の (II) はアセチルイミダゾールの-COCH は $\mathrm{C}_{12} \mathrm{H}_{25} \mathrm{O}\left(\mathrm{CH}_{2} \mathrm{CH}_{2} \mathrm{O}\right)_{8} \mathrm{COCH}_{3}$ であることがわかっ た。そこで PNPA の分解速度及び生成物アセチルイミ ダゾール $\mathrm{C}_{12} \mathrm{H}_{25} \mathrm{O}\left(\mathrm{CH}_{2} \mathrm{CH}_{2} \mathrm{O}\right)_{8} \mathrm{COCH}_{3}$ の生成または分 解速度を調べるために, それぞれのシグナルの高さの時 閒変化を測定し，その結果を Fig.-2 に示した。

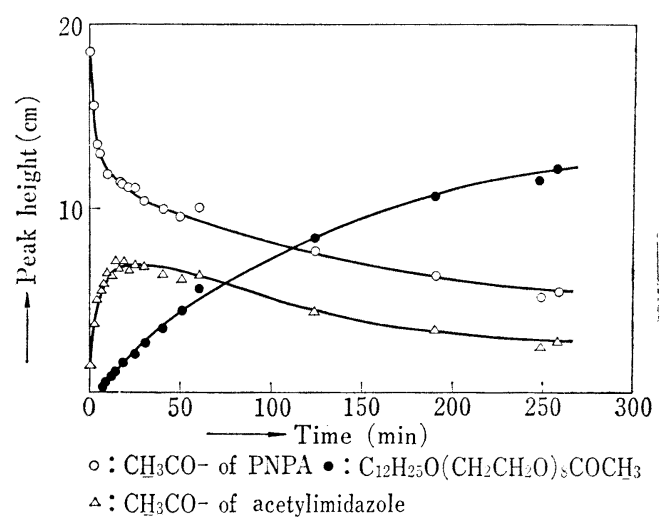

Fig.-2 The change of peak height of NMR signals with time in anhydrous PNPA/ imidazole/DP-8/CCl ${ }_{4}$ systems.

Fig.-2 からわかるように，イミダゾール $\mathrm{DP}-8 / \mathrm{CCl}_{4}$ 系に PNPA を添加すると PNPA は急激に分解を始的, 同時にアセチルイミダゾールが生成し，その後 PNPA とともに徐々に分解していくことがわかる。しかし $\mathrm{C}_{12}$ $\mathrm{H}_{25} \mathrm{O}\left(\mathrm{CH}_{2} \mathrm{CH}_{2} \mathrm{O}\right)_{8} \mathrm{COCH}_{3}$ は PNPA の添加と同時には 生成せず，しばらくしてから徐々に生成した。このこと はイミダゾール $/ \mathrm{DP}-8 / \mathrm{CCl}_{4}$ 系に PNPA を添加すると 同時にアセチルイミダゾールが中間体としてすばやく生 成し始め, それが DP-8 と徐々に反応して $\mathrm{C}_{12} \mathrm{H}_{25} \mathrm{O}$ $\left(\mathrm{CH}_{2} \mathrm{CH}_{2} \mathrm{O}\right)_{8} \mathrm{COCH}_{3}$ が生成することを示していると思 われる。したがってPNPAの分解反応は式 (1) で示され るような, アセチルイミダゾールを中間体とする界面活 性剤の末端ヒドロキシル基へのアセチル転移の遂次一次 反応である。

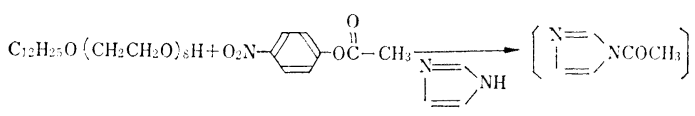

$\longrightarrow \mathrm{C}_{2: 2} \mathrm{H}_{2} ; \mathrm{O}\left(\mathrm{CH}_{2} \mathrm{CH}_{2} \mathrm{O}\right)_{*} \mathrm{COCH}_{3}+\mathrm{O}_{2} \mathrm{~N}-\mathrm{O}-\mathrm{OH} \cdots(1)$ 
同様な結果はまた 1ードデカノール溶液または含水界 面活性剂容液において子得られた。

\section{$3 \cdot 2$ 界面活性剂存在下におけるイミダゾールの 触媒 作用}

ここで用いた界面活性剤または1ードデカノールはそ れ自身 PNPA の分解反応隹対して触媒作用を示さない が，イミダゾールの溶解度を著しく増大させ，同時にそ の触媒作用をも増大させることがわかった。そこで界面 活性剂または 1ードデカノール存在下におけるイミダゾ 一ルの触媒作用を調べるために，イオン界面活性剂の場 合 ${ }^{12)}$ と同様に界面活性浻または 1ードデカノールに対し イミダゾールのモル比を $0.5,1.0,2.0$ とし, その一定 モル比でイミダゾール濃度をかえた時の $k_{\mathrm{obsd}}$ の変化を 測定した。Fig.-3には一例よしてモル比（イミダゾー

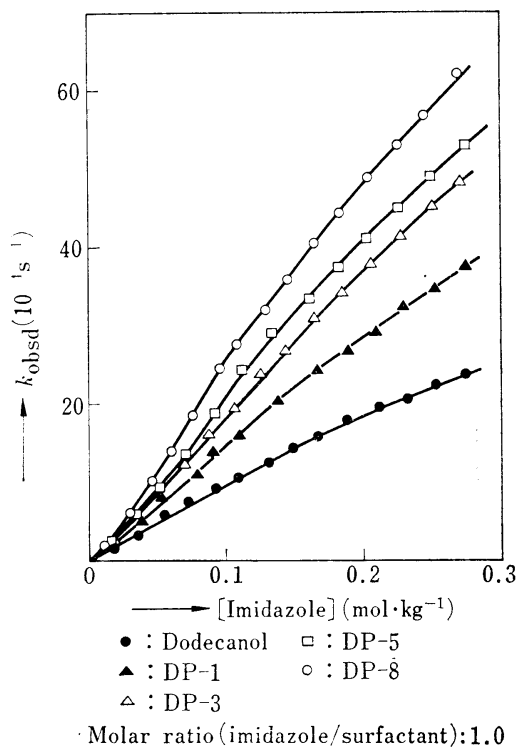

Fig. -3 The change of $k_{\text {obsd }}$ with [Imidazole] in imidazole/surfactants or dodecanol/ $\mathrm{CCl}_{4}$ systems.

ルドデカノールまたは界面活性郕) 1.0 におけるイミダ ゾール濃度による $k_{\mathrm{obsd}}$ の変化を示した。界面活性剂溶 液に打ける $k_{\text {obsd }}$ は，ぞのモル比に扔いてもイミダゾー ル濃度とともに徐々に増加し，高濃度になるにつれて $x$ 軸に回となり，いわゆるS 字型曲線を示した。しかし 1-ドデカノール溶液ではモル比にかかわらず低濃度領域 で直線的に増加しただけで, 高濃度では界面活性郕の場 合と同様に $x$ 軸に対し凹である曲線を示した。このよう な $\mathrm{S}$ 字型 $k_{\mathrm{obsd}}$ 曲線は, ドデシルアンモニウムプロピ

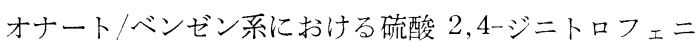
ル塩の分解反応 ${ }^{20)}$ における界面活性剤の $\mathrm{cmc}$ 付近で観 察されている。

そこで本研究で得られた S 字型曲線はイミダゾール添
加による界面活性剤の会合体形成と関連性があるものと 考え，その点を明らかにするために PNPA を含まない イミダゾール $\mathrm{CCl}_{4}$ 系に打ける密度測定及び水の溶解度 実験を行った。ここで界面活性剤または1ードデカノール に対するモル比は一定 (1.0) とした。Fig.-4 に示した

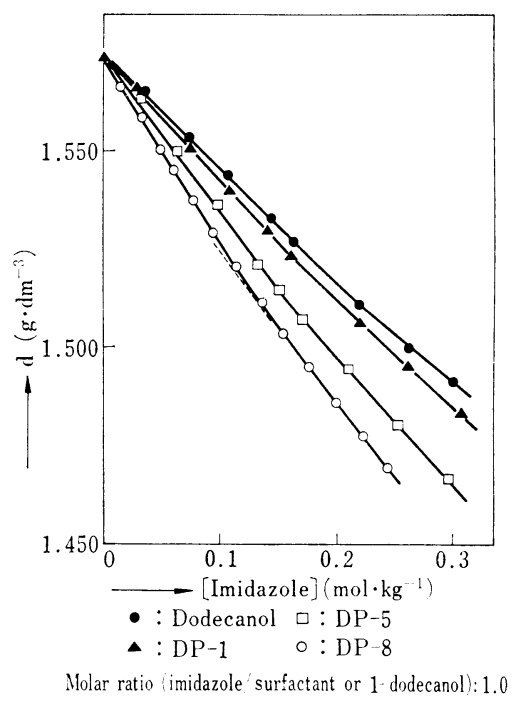

Fig. -4 The plots of density $v$ s. [Imidazole] in imidazole/surfactants or dodecan = $\mathrm{ol} / \mathrm{CCl}_{4}$ systems.

密度測定の結果からわかるように，どの系においても密 度はイミダゾール濃度が増すにつれて減少したが，ある 濃度で屈折点があらわれた。一方, 密度測定をした同じ 溶液に一定量の水を添加し, イミダゾール濃度を変化し ていくと水の溶解度はあるイミダゾール濃度から増し， それ以下では溶液が白濁した。これら密度測定における 屈折点及び水の溶解度が増すところのイミダゾール濃度

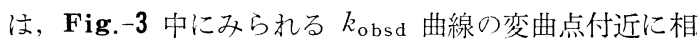
当した。水の溶解度が増加するということはイミダゾー ルー界面活性剤または 1ードデカノール結合体が会合体を 形成することを意味する。したがって $k_{\mathrm{obsd}}$ の変曲点は その結合体の会合体が形成し始める濃度であると推定す るこ々ができる。しかしその会合体の大きさを蒸気圧降 下法によって算出することを試みたが，会合体が小さい ためかイミダゾール界面活性剂結合体モノマーと明確に 区別することができなかった。したがって Fig.-3 にお ける変曲点以下の $k_{\mathrm{obsd}}$ はイミダゾール界面活性剤また はドデカノール結合体のモノマー（以下イミダゾールモ ノマーと呼ぶ）による值であり，それ以上の $k_{\mathrm{obsd}}$ はイ ミダゾール界面活性剤または 1ードデカノール結合体の 会合体（以下イミダゾール会合体と呼ぶ）による值であ るとみることができる。

変曲点以下の濃度に㧍ける $k_{\mathrm{obsd}}$ は式 (2) で表すこ 


$$
\begin{aligned}
k_{\mathrm{obsd}} & =k_{2, \mathrm{~m}}[\text { イミダゾール }] \\
& +k_{3}, \mathrm{~m}[\text { イ ミダゾール }]^{2}
\end{aligned}
$$

とができるので，Fig.-5 に示した $k_{\text {obsd// }} /[$ イダゾー ル〕 と[イミダゾール］の直線の切片とこう配からそれ ぞれイミダゾールモノマーによる二次速度定数 $k_{2, \mathrm{~m}}$ と 三次速度定数 $k_{3, \mathrm{~m}}$ を算出した。一方 1-ドデカノール 溶液に扔ける $k_{2, \mathrm{~m}}$ は低濃度領域における直線のこう配 から求奻た。得られた值はまとめて Table-1 に示し た。

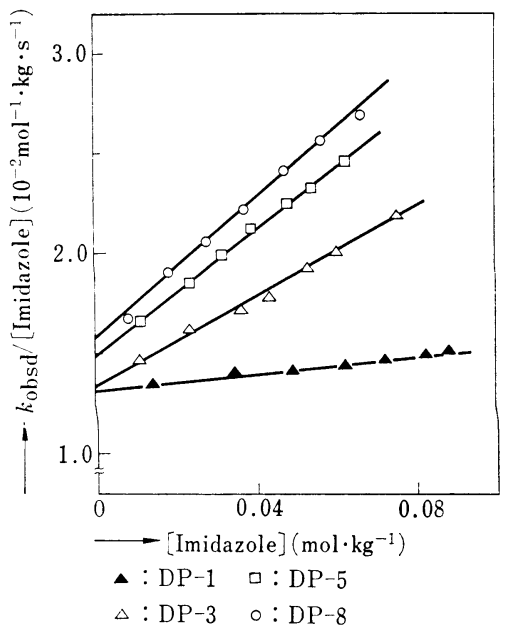

Molar ratio (surfactants or dodecanol): 1.0

Fig. -5 The plots of $k_{\mathrm{obs}} /[$ Imidazole $]$ vis. [Imidazole] on imidazole monomer.

Table-1 Rate constant parameters in imidazole nonionic surfactants or dodecanol/ $/ \mathrm{CCl}_{\text {i }}$

\begin{tabular}{|c|c|c|c|c|c|}
\hline Surfactant & $\begin{array}{l}\text { Molar } \\
\text { ratio }\end{array}$ & $\begin{array}{l}k_{2, \mathrm{~m}} / \\
10^{-211}\end{array}$ & $\begin{array}{l}k_{3, \mathrm{~m}} / \\
\left.10^{-2} 2\right)\end{array}$ & $\begin{array}{l}k_{\mathrm{A}} / \\
10^{-233}\end{array}$ & $\begin{array}{l}k_{\mathrm{AE}} / \\
\mathrm{mol} \cdot \mathrm{kg}^{-1}\end{array}$ \\
\hline \multirow{3}{*}{ 1-Dodecanol } & 0.5 & 0.95 & - & 0.57 & 0.77 \\
\hline & 1.0 & 1.30 & - & 0.79 & 0.64 \\
\hline & 2.0 & 1.50 & 一 & 2.03 & 1.11 \\
\hline $\mathrm{DP}-1$ & 1.0 & 1.30 & 7.0 & 1.67 & 0.95 \\
\hline $\mathrm{DP}-3$ & 1.0 & 1.33 & 11.0 & 2.27 & 1.02 \\
\hline \multirow[t]{2}{*}{ IDP $\cdots$} & 1.0 & 1.47 & 17.0 & 2.86 & 1.23 \\
\hline & 0.5 & 1.37 & 14.0 & 2.00 & 0.95 \\
\hline \multirow[t]{2}{*}{ D) $P-8$} & 1.0 & 1.57 & 17.0 & 3.81 & 1.41 \\
\hline & 2.0 & 1.78 & 17.5 & 5.99 & 1.82 \\
\hline
\end{tabular}
systems at $30^{\circ} \mathrm{C}$.

1) $: \mathrm{kg} \cdot \mathrm{mol}^{-1} \cdot \mathrm{s}^{-1}$

2) $: \mathrm{kg}^{2} \cdot \mathrm{mol}^{-2} \cdot \mathrm{s}^{-1}$

3) $: \mathrm{s}^{-1}$

一方, 変曲点以上の $k_{\mathrm{obsd}}$ は Fig.-3 から, 近似的に 式 (3)のスキームによって導かれる Michaelis-Menten の式 (4)にしたがうと考えられる。

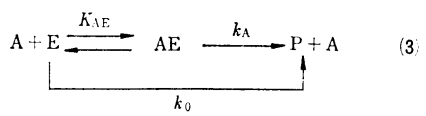

ここでAはイミダゾール会合体， $\mathrm{E}$; エステル $(\mathrm{PN}=$ PA), AE; イミダゾール会合体とエステルの Complex, $\mathrm{P}$; 生成物, $k_{0}$; 純溶媒中における反応速度定数, $k_{\mathrm{A}}$; イミダゾール会合体の反応速度定数， $K_{\mathrm{AE}}$; イミダゾー ル会合体とエステルとの Complex の平衡定数を示す。 式(3) 加ら

$$
k_{\mathrm{obsd}}=\frac{\left.k_{0}+k_{\mathrm{A}} K_{\mathrm{AE}}\left\{C_{\mathrm{s}}-\mathrm{cmc}\right) / n\right\}}{1+K_{\mathrm{AE}}\left\{\left(C_{\mathrm{s}}-\mathrm{cmc}\right) / n\right\}}
$$

ここで $C_{\mathrm{s}}$ はイミダゾール濃度, $\mathrm{cmc}$ はイミダゾール 会合体の形成濃度, $n$ はイミダゾール会合体の会合数を 示す。式 (4) において, cmc を密度測定に扔ける屈折 点から見積ったにしても， $n$ は前に述べたように小さく 測定しにくい。したがって会合体濃度 $\left(C_{\mathrm{s}}-\mathrm{cmc}\right) / n$ を 算出することができないばかりか， cmc 以上でイミダゾ ールモノマーの濃度が一定であると仮定することができ

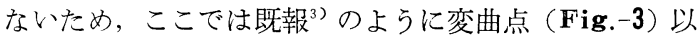
上の $k_{\mathrm{obsd}}$ に対し $\mathrm{cmc}$ での $k_{\mathrm{obsd}}, \mathrm{cmc}$ の補正をする ことができない。

そこで本研究では $\left(C_{\mathrm{s}}-\mathrm{cmc}\right) / n$ の代わりに $C_{\mathrm{s}}$ を用 い， $k_{0}=0^{3)}$ として式 (4) を変形し，式（5）を得た。

$$
\frac{1}{k_{\mathrm{obsd}}}=\frac{1}{k_{\mathrm{A}} K_{\mathrm{AE}} C_{\mathrm{s}}}+\frac{1}{k_{\mathrm{A}}}
$$

Fig.-6に $1 / k_{\text {obsd }}$ と $1 / C_{\mathrm{s}}$ をプロットし，得られた 直線の切片とこう配からそれぞれ $k_{\mathrm{A}}$ 及び $K_{\mathrm{AE}}$ を算出 し，それらの值を Table-1 に示した。

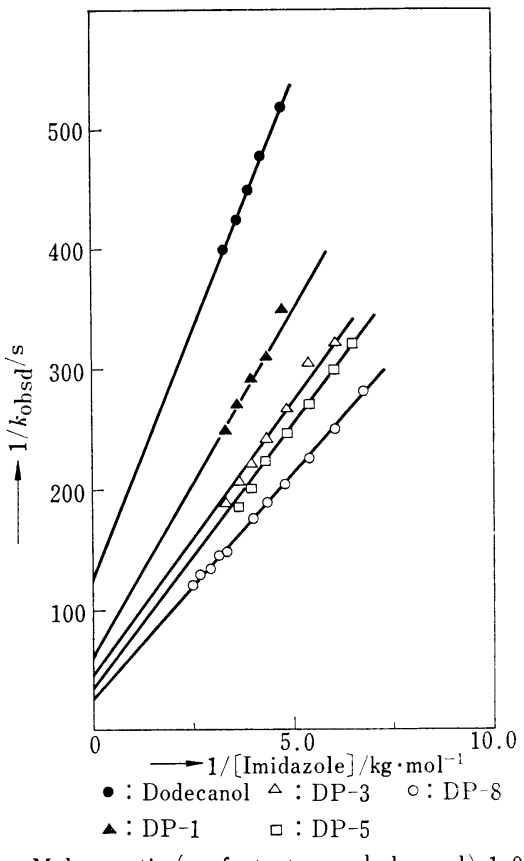

Molar ratio (surfactants or dodecanol): 1.0

Fig.-6 The plots of $1 / k_{\text {obsd }}$ vs. $1 /$ [Imidazole] on imidazole aggregates. 
最初にイミダゾールモノマーによる速度定数 $k_{2}, \mathrm{~m}$, $k_{3}, \mathrm{~m}$ についてみると, $k_{2, \mathrm{~m}}$ 值は 1 -ドデカノール及び DP-8 溶液でモル比とともに増大したが, 界面活性刘の オキシエチレン鎖長による効果（モル比：1.0) はわず かに増大する傾向を示すだけであった。 $k_{3, \mathrm{~m}}$ は 1 -ドデ カノール溶液では得られなかったが, モル比またはオキ シエチレン鎖長の増加により飽和する傾向を示した。一 方, イミダゾール会合体による $k_{\mathrm{A}}$ は $k_{2}, \mathrm{~m}$ と同様にモ ル比及びオキシエチレン鎖長とともに増大し, その効果 はモノマーの場合よりも大きかった。また $K_{\mathrm{AE}}$ 值もオ キシエチレン鎖長とともに増加した。特にオキシエチレ ン鎖長による効果（モル比：1.0）については， $k_{\mathrm{A}}$ に対 しオキシエチレン基数をプロットしてみると直線関係が 得られ，そのこう配から単位オキシエチレン基あたりの $k_{\mathrm{A}}$ の増加率が求められ, その值は $0.31 \times 10^{-2} \mathrm{~s}^{-1}$ であ った。ここで $k_{2, \mathrm{~m}}$ に対しオキシエチレン鎖長効果がわ ずかしかみられないのは, モノマー状態にあるほとんど のイミダゾール分子が1-ドデカノールまたは界面活性剤 の末端ヒドロキシル基と相互作用し, オキシエチレン基 とはほとんど相互作用しないことを示唆している。しか しイミダゾール濃度が増すにつれてイミダゾールと界面 活性剤の間に会合体が形成してくると, イミダゾール分 子はヒドロキシル基との他にオキシエチレン基とも相互 作用するよらになるので速度定数のオキシエチレン鎖長 効果が表れるようになったものと考えられる。ここで界 面活性片と同様に 1-ドデカノール溶液において $k_{\mathrm{A}}$ が 算出できたのは, ドデカノールのヒドロキシル基と相互 作用するイミダゾール分子がさらに他のイミダゾール分 子と相互作用し会合体を形成することによるものと考え られる。

\section{$3 \cdot 3$ 可溶化水中におけるイミダゾールの触媒作用}

本研究で用いた界面活性剂のうち, DP-8 がもっとも 水の可溶化能が大きいので, その溶液におけるイミダ ゾールの触媒作用に及ぼす水の効果について調べた。

Fig.-7 にはモル比（イミダゾール/DP-8）が 0.5, 1.0, 2.0 の界面活性剤溶液における $k_{\mathrm{obsd}}$ の水濃度による变 化を示した。Fig.-7 から明らかなように, どのモル 比 においても $k_{\mathrm{obsd}}$ は水濃度とともに増加し, ある濃度以 上で飽和值に達した。同様な $k_{\mathrm{obsd}}$ 曲線はまた $\mathrm{D}_{2} \mathrm{O}$ 添 加においてもみられた。このように $k_{\mathrm{obsd}}$ が水の高濃度 領域で飽和值を示す反応は, すでに O'Connor ら ${ }^{21} に$ よるアルキルアンモニウムカルボキシラートのベンゼン 溶液における bis (oxalato) diaquochromate (III) の トランスーシス異性化反応に抢いて観察されている。そ こで O'Connor らと同様に $k_{\text {obsd }}$ の飽和值 (それぞれ を $k_{\mathrm{obsd}}^{\mathrm{H} 2 \mathrm{O}}$ または $k_{\mathrm{obsd}}^{\mathrm{D} 2 \mathrm{O}}$ とする) から水の同位体効果 について調べた結果, $k_{\mathrm{obsd}}^{\mathrm{H} 2 \mathrm{O}} / k_{\mathrm{obsd}}^{\mathrm{D} 2 \mathrm{O}}$ はモル比が 0.5 のと き $1.6,1.0$ で $1.3,2.0$ で 1.2 となった。このことか

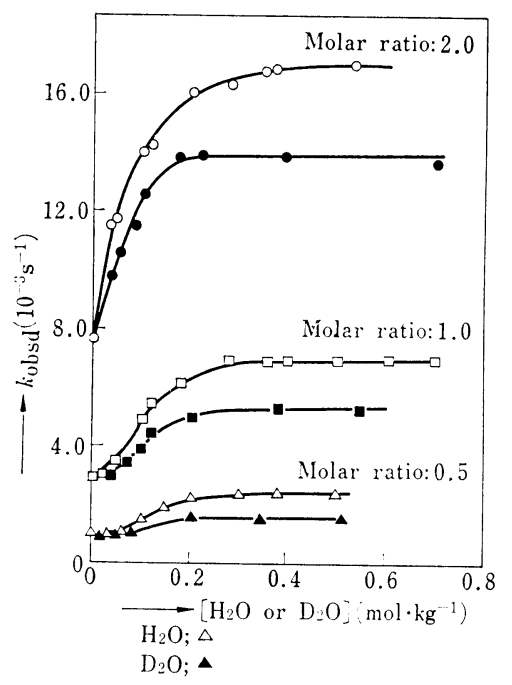

Fig. -7 The change of $k_{0 \text { osdi }}$ is. $\left.\left[\mathrm{H}_{2} \mathrm{O} \text { or } 1\right)_{2} \mathrm{O}\right]$ in imidazole/DP-8/CCl systems.

らイミダゾールはモル比にかかわらず求核触媒として作 用することがわかった。1ーピリジンオキシドの最大吸収 波長核境の極性の大きさによっ下変化する。これを利 用して環境の極性を評価することができる(3),15)。そこで 同じ溶液にピリジン 1ーオキシドを添加し，UV 測定よ りその吸収波長を測定し可溶化水の極性の大きさの評価 試みた。その結果 1 -ピリジンオキシドの波長の值は $k_{\mathrm{obsd}}$ の場合と同様にある水濃度から飽和值を示した。 そこでその波長の飽和值と Fig.-7 で得られた $k_{\mathrm{obsd}}^{\mathrm{H} 2 \mathrm{O}}$ の関倸を調べるために，Fig.-8にそれぞれの值をモル 比に対してプロットしたところ，いずれの值もモル比之 直線関倸にあった。すなわちモル比の増大とともに可溶 化水の極性法減少し, 逆に $k_{\mathrm{obsd}}^{\mathrm{H} 2 \mathrm{O}}$ は増大した。したが って可溶化水中におけるイミダゾールの触媒作用は, 可 溶化水の極性が減少するとともに增大するものと考えら

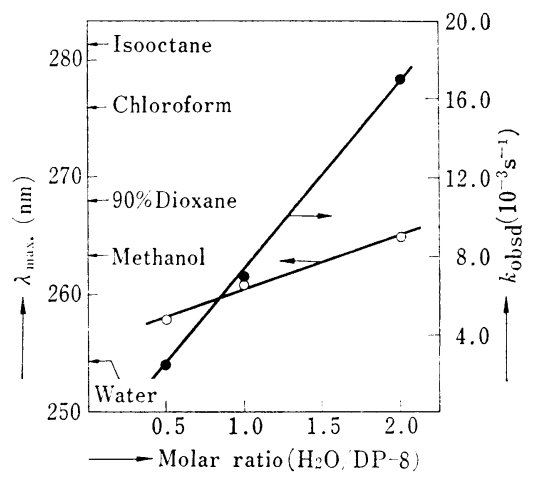

Fig.-8 The relationship between polarity of water solubilized and $k_{\mathrm{obsd}}^{\mathrm{H} 2 \mathrm{O}}$ in imid= azole/DP- $8 / \mathrm{CCl}_{4}$ systems. 
れる。このように可溶化水の極性が減少するとともに反 応速度定数が増大寸るといら事実は, Senō ら ${ }^{4)}$ にる ドデシルアンモニウムプロピオナート逆ミセルによるア デノシン -5'-トリホスファートの加水分解反応において 観察されている。

第 17 回油化学討論会・油化学研究発表会にて一部発表。 (昭和 55 年 2 月 28 日受理)

\section{文献}

1) J.H. Fendler, E.J. Fendler, "Catalysis in Micellar and Macromolecular Systems", Academic Press, New York (1975) p. 339

2) K.Kon-no, K. Miyazawa, A. Kitahara, Bull. Chem. Soc. Jpn., 48, 2955 (1975)

3）今野紀二郎, 松山隆夫, 水野浩之, 北原文雄, 日化, 1975,1857

4) M. Senō, S. Shiraishi, K. Arai, H. Kise, Bull. Chem. Soc. Jpn., 48, 3678 (1975)

5) K.J. Mollett, C.J. O'Connor, J. Am. Chem. Soc., 100, 5910 (1978)

6) A. Kitahara, K. Kon-no, "Micellization, Solubili= zation and Macroemulsions" vol. 2 ed. by K.L. Mittal, Plenum Press, New York (1977) p. 675

7) T.D. Lomax, C.J.O'Connor, J. Am. Chem. Soc., 100, 5910 (1978)

8) H. Kondo, K. Fujiki, J. Sumanoto, J. Org. Chem.,
43, 3584 (1978)

9）今野紀二郎, 永延弘道, 北原文雄, 油化学, 29, 517 (1980)

10) O.A. ElSeoud, A. Martins, L.P. Barber, M.J. da Silva, V. Aldrigue, J. Chem. Soc. Perkin II., 1977, 1674

11) U. Tonellato, J. Chem. Soc. Perkin II., 1979, 307

12) K. Kon-no, A. Kitahara, M. Fujiwara, Bull. Chem. Soc. Jpn., 51, 3165 (1978)

13) K.Kon-no, A. Kitahara, J. Colloid Interface Sci., 67, 477 (1978)

14）今野紀二郎, 勝田正美, 中村顕二, 森 寊光, 北原文雄, 日化, 1980, 435

15) F.M. Menger, J.A. Donohue, R.F. Williams, J. Am. Chem. Soc., 95, 286 (1973)

16) K. Martinek, A.V. Levashov, N.L. Klyachko, O.V. Berezin, Dok. Akad. Nauk USSR, Engl. Ed., 236, 951 (1978)

17) F.M. Menger, K. Yamada, J. Am. Chem. Soc., 101. 6731 (1979)

18) A. Kitahara, J. Phys. Chem., 69, 2788 (1965)

19) E.A. Guggenheim, Phil. Mag., 2, 538 (1926)

20) C.J. O'Connor, E.J. Fendler, J.H. Fendler, J. Org. Chem., 38, 3371 (1973)

21) C.J. O'Connor, E.J. Fendler, J.H. Fendler, J. A $1 m$. Chem. Soc., 95, 600 (1973) 